\title{
FROM THE KRAKÓW COLLECTION: TWO PENCIL SKETCHES BY NORWID
}

Most of Norwid's visual works are kept in public collections, which makes it highly unusual for any drawings, watercolours, oil paintings or even prints to appear on the antiques market. Little wonder then that two sketches by Norwid listed for sale in 2019 by the art gallery Salon Dzieł Sztuki Connaisseur in Kraków figured prominently (apart from the painting Ruda by Wojciech Weiss, and Panorama tatrzańska by Stanisław Kamocki) in the announcement of the November auction posted on the gallery's website. ${ }^{1}$ Interest in drawings from the collection of the Kraków-based art historian Lech Kalinowski (1920-2004) was immense, according to Maciej Jakubowski, the owner of the Salon. Naturally, the two pencil drawings done on the same thick, warm white paper were immediately sold under the following titles: Odpoczynek podczas ucieczki do Egiptu [Rest During Flight to Egypt] (13 x $14 \mathrm{~cm}$, fig. 1) and Ostatnia wieczerza. Ujawnienie zdrajcy [The Last Supper. Disclosure of the Traitor] $(14.5 \times 16 \mathrm{~cm}$, fig. 3). Notably, the former is well known among scholars and admirers of Norwid, whereas the latter has not been referenced in literature yet.

Odpoczynek podczas ucieczki do Egiptu was first reproduced in a publication by Zenon Przesmycki in 1914 in volume E of Norwid's Pisma zebrane. ${ }^{2}$ Undoubtedly, the editor properly recognized the iconographic character of the drawing. This apocryphal theme was highly popular in art, especially during the Renaissance and the baroque. Norwid's piece follows the iconographic tradition, although it strongly emphasizes - in accordance with the strategy adopted by the

\footnotetext{
${ }^{1}$ https://koneser.krakow.pl/pl/aktualnosci/135-nowe-obiekty-w-listopadowej-ofercie (accessed 4 December 2019).

${ }^{2}$ The actual date od publication was later than the one provided on the titled page (1911). The reproduction is on page 64 , while its description, containing the title - on page 320 .
} 
artist - the genre character of the scene. The sketch presents Mary and Joseph sitting on a rock and sleeping off the hardships of their journey. Sitting on the mother's knee, the child is the only figure that remains awake and is looking in our direction. The composition is limited to this tight group, which is presented on a neutral background.

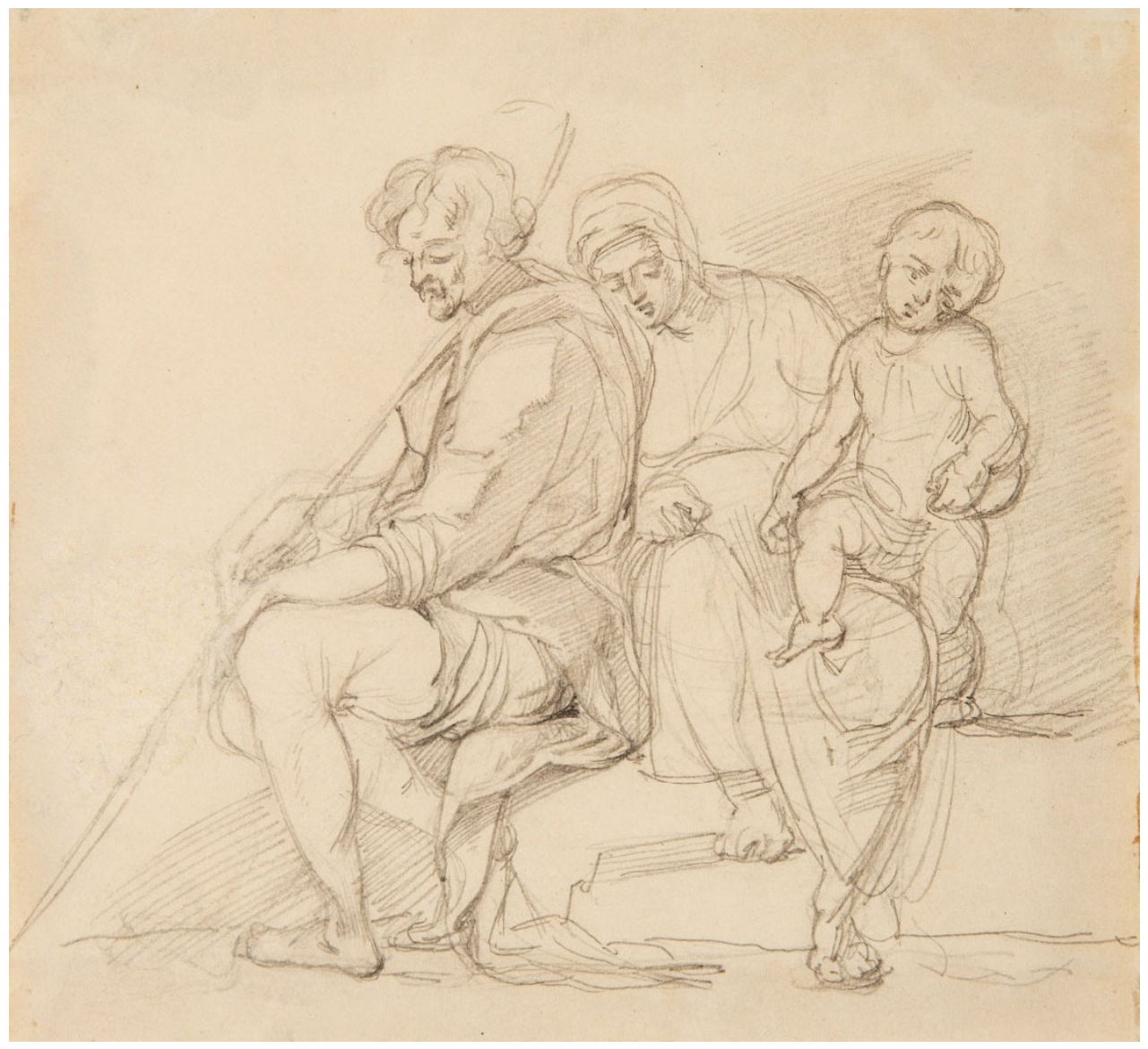

Fig. 1. C. Norwid, Odpoczynek podczas ucieczki do Egiptu [Rest during Flight to Egypt], [1846]

In a note containing detailed information about the drawing, Przesmycki reveals that it was found in Norwid's sketchbook, which used to belong to Adolf Sternschuss and is currently stored in the collection of the National Museum in Kraków (inv. no. III-r.a. 1894). Its earlier history is also well known: along with two other sketchbooks it was donated by Norwid to the family of General Jan Skrzynecki when the poet stayed in Brussels at the turn of 1846 and 1847. Before 
1914, the sketchbooks were sold by Zofia Skrzynecka, the General's daughter, to the Kraków collector Adolf Sternschuss, and after his death were donated by his siblings in 1916 to the National Museum in Kraków. ${ }^{3}$ Przesmycki's manuscript archive, specifically the collection Materiały do twórczości malarskiej i rysowniczej Cypriana Norwida, contains a detailed description of the sketchbook from the period when it was owned by Sternschuss. ${ }^{4}$ This description reveals a number of differences between the sketchbook's state at that time and today, arising from the removal of eleven plates with pencil sketches done directly in the sketchbook (including three signed plates). ${ }^{5}$ The integrity of the sketchbook was broken somewhere between 1914 and 1916, although the exact circumstances of this remain unknown. According to Miriam, Odpoczynek podczas ucieczki do Egiptu used to be plate number 27 (its dimensions being $18.3 \times 27.2 \mathrm{~cm}$ ), along with an unrelated sketch of a man wearing a coat and a top hat, situated closer to the left edge of the page (fig. 2). Several reproduction photographs of the entire page are luckily preserved in Przesmycki's archive, which allows us to glimpse the original state of this piece. ${ }^{6}$ After the plate was removed from the sketchbook, the drawings were separated and their later fate remained unknown until the drawing presenting the Holy Family was put on sale by Salon Dzieł Sztuki Connaisseur with the information that it comes from the collection of Lech Kalinowski.

Later fate of the other plates removed from the sketchbook remains largely unknown. Several drawings were published in the press or elsewhere, while one unpublished reproduction photo is stored in Miriam's photography archive at the National Museum. ${ }^{7}$ In recent years, however, it became possible to recognize two pencil drawings presenting noble old men as coming from the sketchbook in question. One of them, which presents a bearded old man holding an oil lamp, signed using a decorative, interlocking monogram "CKN 1846" (fig. 4), is kept

3 See: E. Chlebowska, Cyprian Norwid. Katalog prac plastycznych, vol. 1: Prace w albumach 1, Lublin 2014, pp. 307-497 (hereinafter referred to as Katalog, with Roman numerals indicating the volume and Arabic ones referring to the page number or catalogue number if preceded by the word "item.").

${ }^{4}$ Biblioteka Narodowa, manuscript signature III 6330, k. 421-444.

5 See: Katalog I, 431-432 (register of plates removed from the sketchbook).

${ }^{6}$ Biblioteka Narodowa, inv. no. F.346-348. One of the photographs bears the seal of a Viennese photographer's shop "C. Angerer \& Göschl" (inv. no. F. 346; dimensions: 13.2 x 17 cm.).

${ }^{7}$ Metternich odznaczajacy Jakuba Szele (published in: Clar., "Z prywatnych zbiorów," Świat 1910, no. 2, p. 7), Joachim Lelewel i nietoperze (published among other places in: Rysunki i grafika K. C. Norwida, Warszawa [1946], plate 3), Scena przy źródle (published in: S. Wasylewski, Sztambuch. Skarbnica romantyzmu, Warszawa 1922, pages not numbered), and Postać męska i scena w karczmie (archival photograph in the collection of Biblioteka Narodowa, inv. no. F. 106, F. 107). 


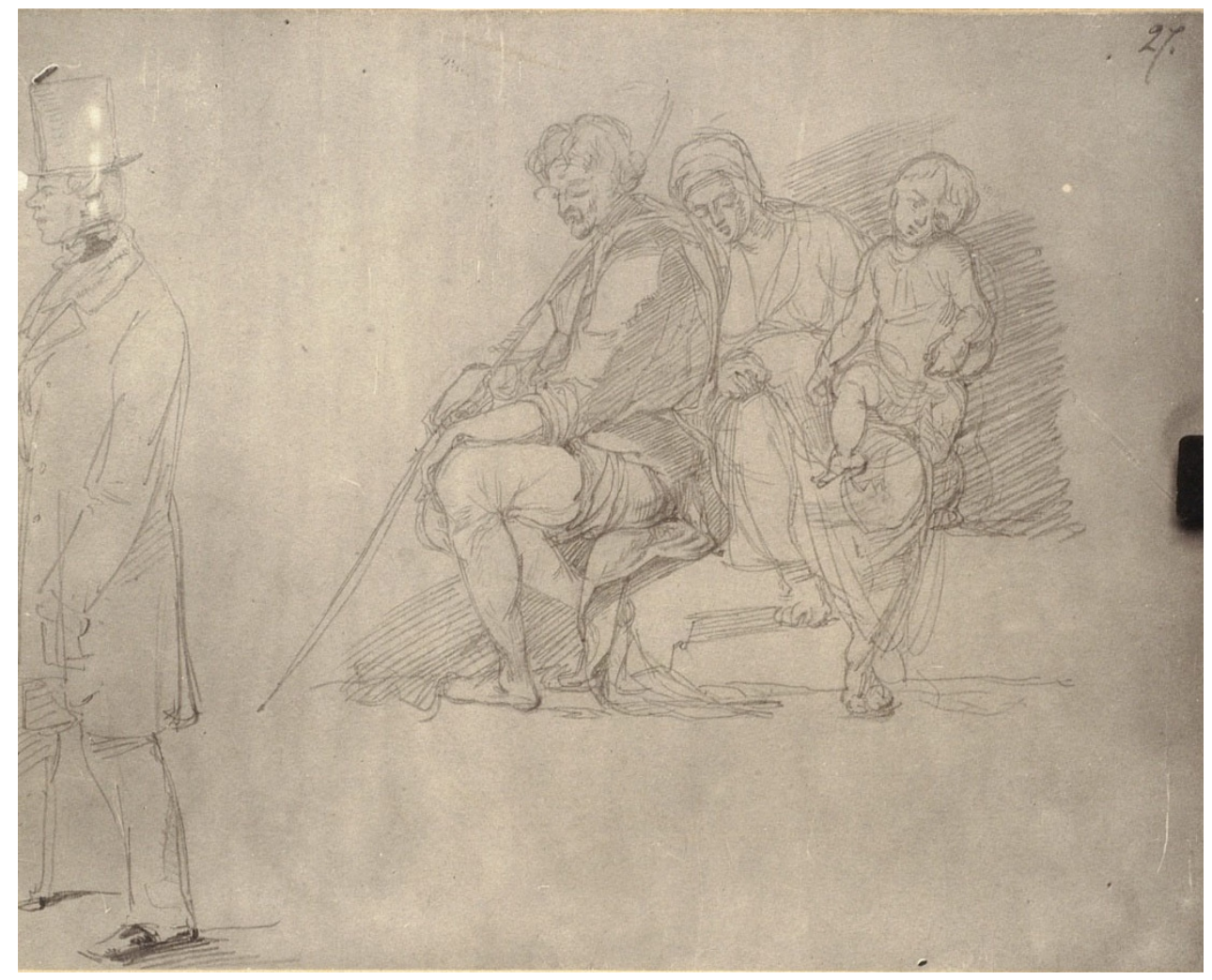

Fig. 2. C. Norwid, Postać męska i odpoczynek podczas ucieczki do Egiptu [A Male Figure and Rest during Flight to Egypt], [1846]

in the National Museum in Warsaw (inv. no. Rys.Pol.190 071), where it was deposited most probably before the war since the museum documentation lacks any information about its origin. ${ }^{8}$ The second sketch of an old man, analogously signed "CKN," is part of a private collection, purchased several years ago from its previous owner, a resident of Kraków.

Norwid's second drawing from the collection of Lech Kalinowski, which was given the title Ostatnia wieczerza. Ujawnienie zdrajcy by the Connaisseur gallery, is not mentioned in literature. The sketch is discreetly signed in pencil in the lower, right-hand corner: "C. Norwid." The piece presents a group of three people wearing antiquity-styled robes. On the left, a bearded old man supports himself on

${ }^{8}$ Katalog III, 196, item 548, illustration on p. 197.

9 Ibid., p. 194, item 547, illustration on p. 195. See also: E. ChlebowsKa, 'Portret matrony' i 'Starzec'. Nieznane rysunki Norwida, "Studia Norwidiana” 36: 2018, pp. 186-188, 193, fig. 5. 


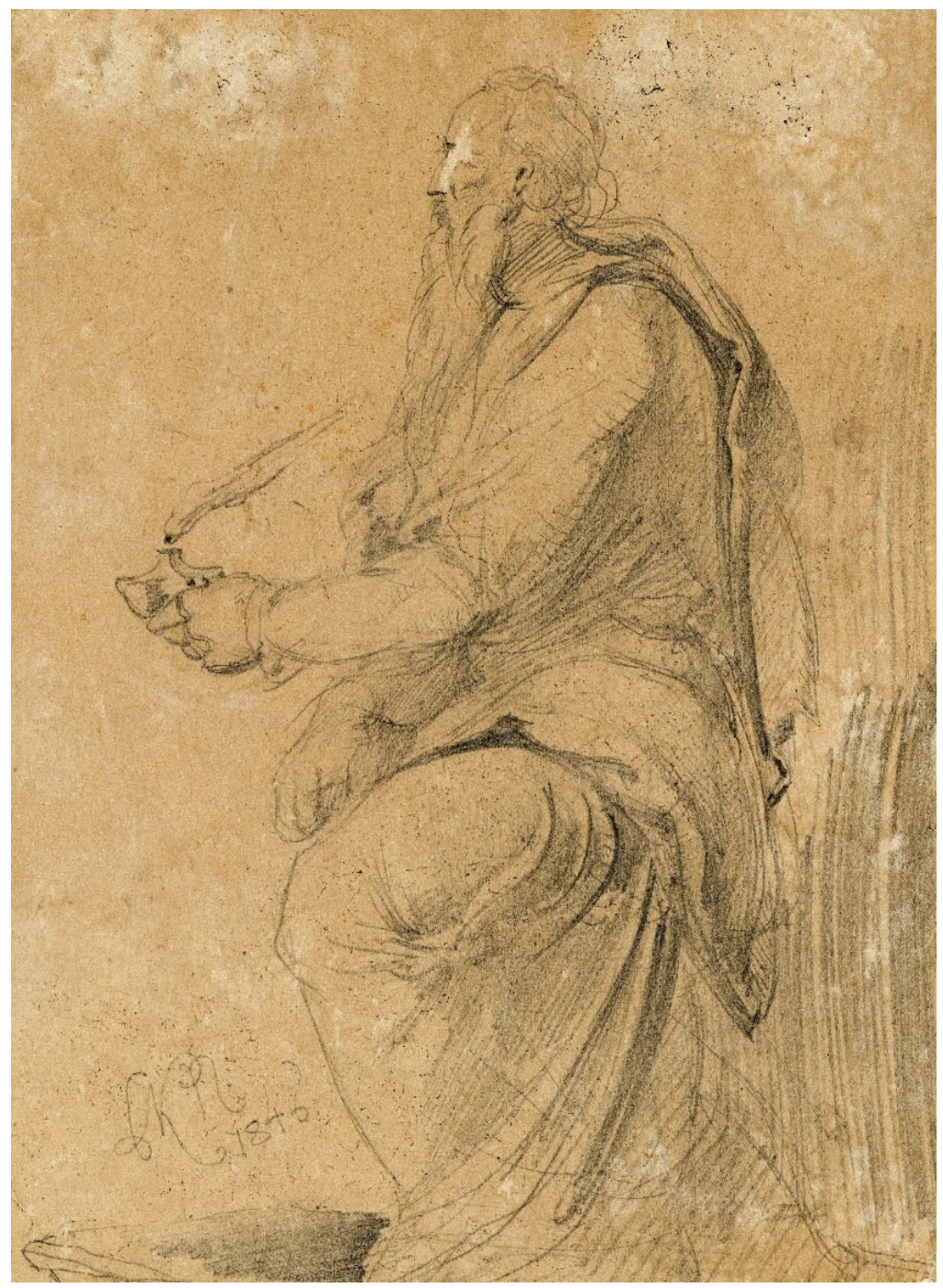

Fig. 3. C. Norwid, Starzec z lampka oliwna [Old Man with an Oil Lamp], 1846

a cane, looking towards a younger man who is sitting on the right and facing him. Another figure is sitting next to him, probably also a man, who is leaning forward and supporting his head on folded hands. The sketch is general in character and lacks details - the facial features of the figures are generic and symbolic. The website of the gallery describes it in the following manner: "The work presents the Last Supper, with Jesus handing a piece of bread to Judas (on the left), thus 


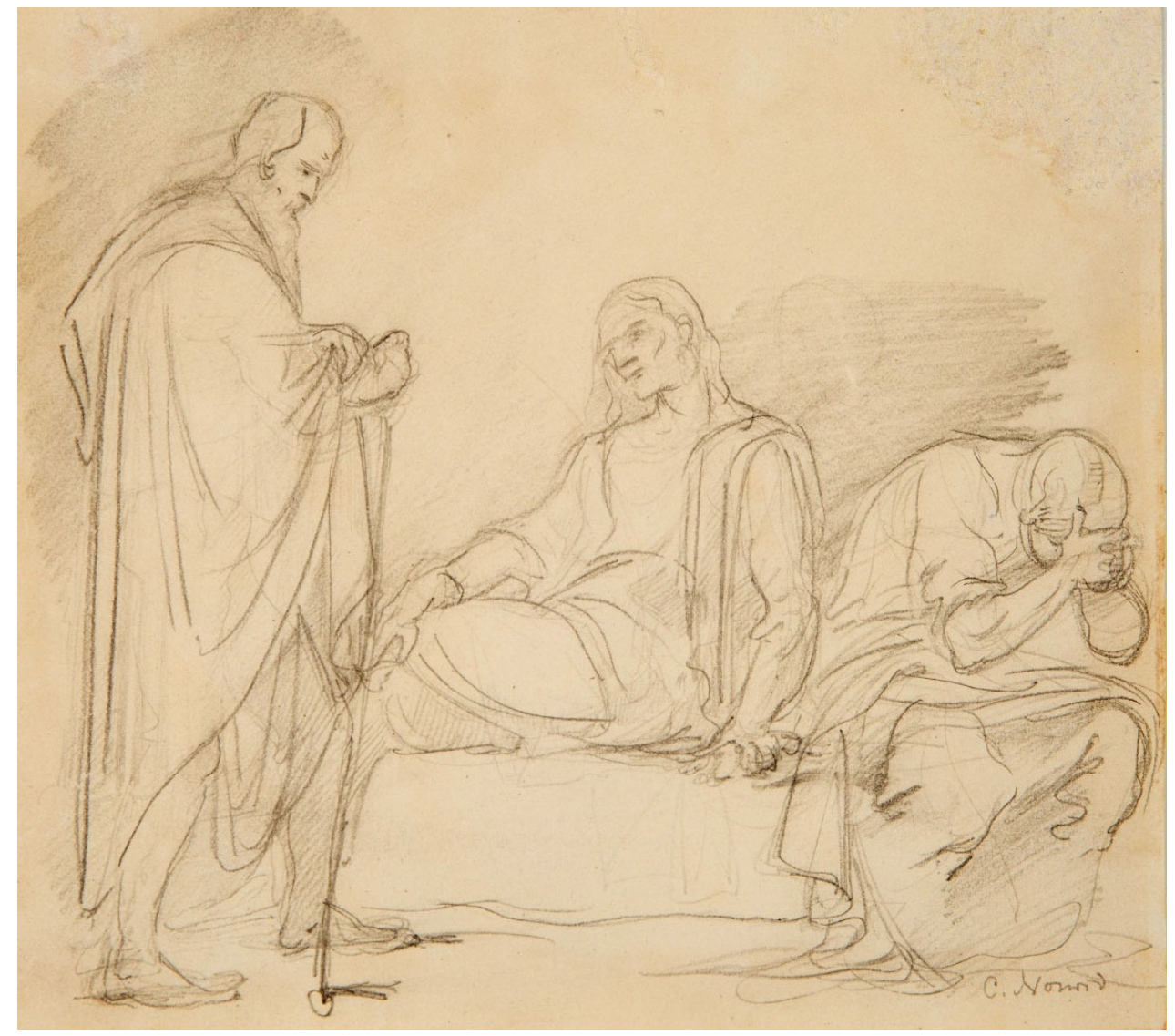

Fig. 4. C. Norwid, Starzec z laska i dwie siedzace postaci [Old Man with a Cane and Two Seated Figures], [1846]

confirming that he knows his intentions. On the right-hand side, we can see the beloved disciple of Christ - Saint John." ${ }^{10}$ However, such interpretation of the subject matter, formulated for the purpose of auctioning the drawing, is doubtful. It is indeed difficult to ascertain that the noble bearded figure is actually Judas Iscariot, especially upon comparison with other representations of the betraying Apostle from Norwid's oeuvre, e.g. the sketch from the album of Michalina Zaleska née Dziekońska (fig. 5) and the scene titled Chrystus w domu Lazarza w Betanii [Christ in the House of Lazarus in Bethany] (fig. 6). Norwid would typically present Judas judgmentally, emphasizing - through a characteristic, almost caricatural grimace -

${ }^{10}$ https://koneser.krakow.pl/pl/oferta/1413-cyprian-kamil-norwid-ostatnia-wieczerza-uja wnienie-zdrajcy?offset $=3$ (accessed 4 December 2019). 


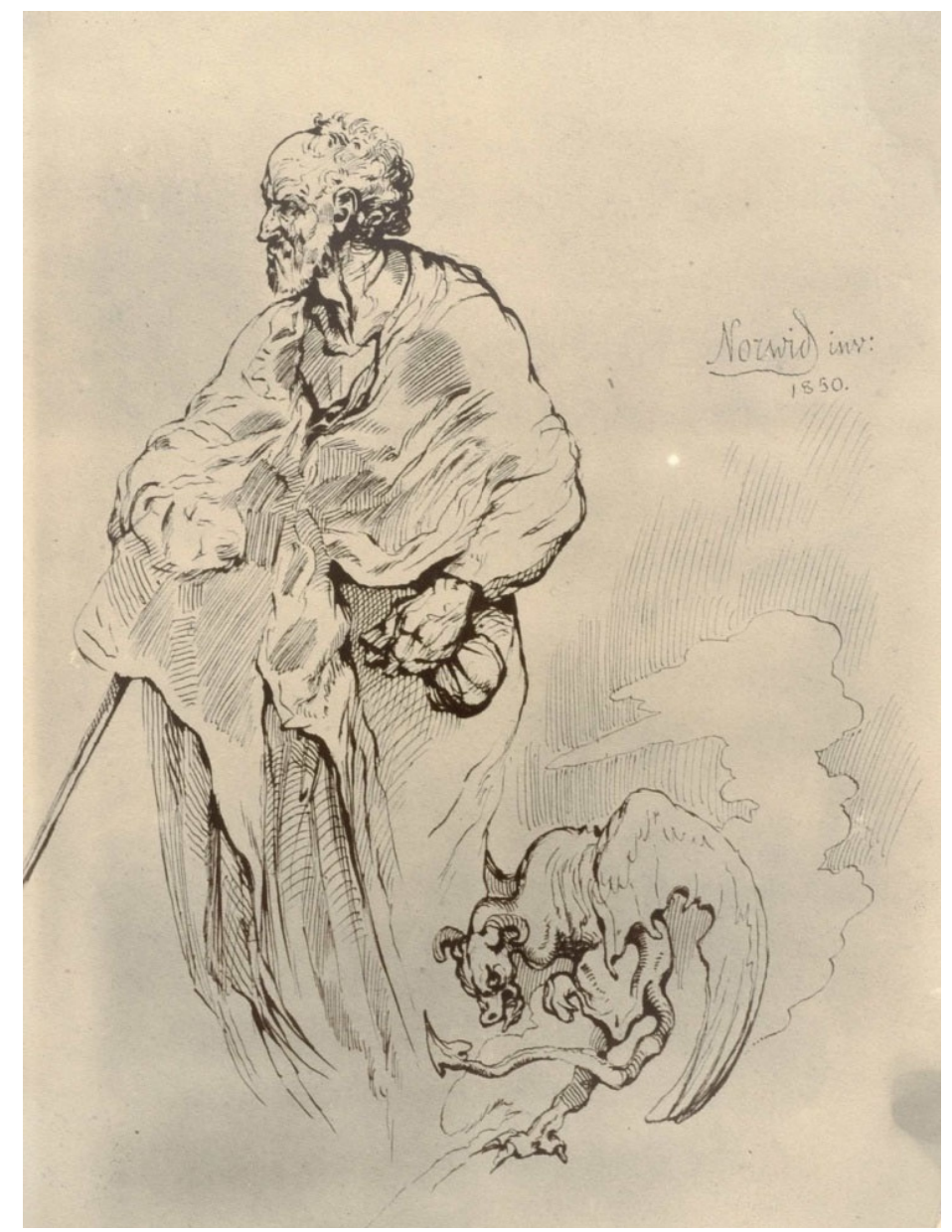

Fig. 5. C. Norwid, Judasz [Judas], 1850

the moral assessment of the Apostle, who is marked by evil. Images of other people in this scene also do not incline one to accept the proposed identification of the subject matter. First of all, the alleged figure of Jesus Christ is not idealized, which is typical for Norwid, who would favour depicting the profile for this reason. ${ }^{11} \mathrm{Fi}$ nally, the sketch in question does not refer to traditional iconography related to this

${ }^{11}$ I have written more extensively on this subject in the article Szmaragd cesarza Tyberiusza - 'prawdziwe' wizerunki Chrystusa w twórczości Norwida, "Studia Norwidiana" 36: 2018, pp. 117-140. 


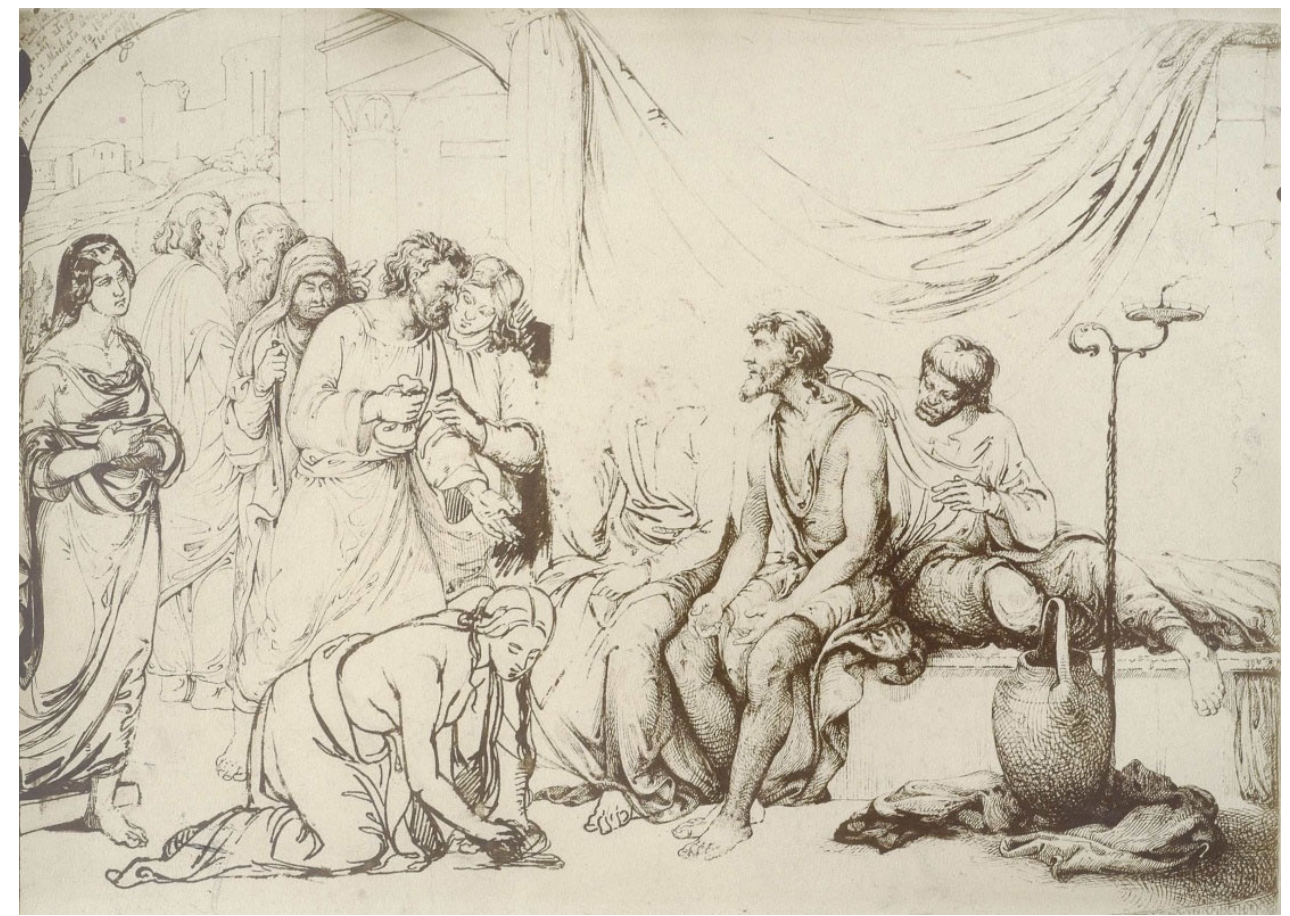

Fig. 6. C. Norwid, Chrystus w domu Lazarza w Betanii [Christ in the House of Lazarus in Bethany], 1845

subject, which is usually incorporated into broader depictions of the Last Supper. It seems that the subject was identified on the basis of a loose association provoked or augmented by the subject matter of the other drawing by Norwid on offer, which illustrates a certain episode from the life of Jesus.

Rejection of the identification proposed by the Connaisseur gallery should involve taking steps towards recognizing the proper or at least more probable subject of Norwid's intimate sketch. The antiquity-styled clothes worn by the figures do not provide sufficient information, nor does the enigmatic character of the scene. Therefore, for the purpose of Katalog prac plastycznych Norwida, I have decided to provide the following title: Starzec z laska $i$ dwie siedzace postaci [Old Man with a Cane and Two Seated Figures] - one that does not define the depicted subject. It is worth mentioning that Norwid's body of visual works features many compositions whose subject matter is difficult to establish. Waleria Marrene-Morzkowska noticed this aspect of his artistic output when he was still alive, referring specifically to his late works. The following opin- 
ion could be generalized and easily regarded as pertaining to his drawings and paintings:

Capitalizing on his illuminating skills, [Norwid] would illustrate his own concepts. Hence his drawings became much like hieroglyphs that require a key to be understood. Beautiful figures and shapes could be found in them, but what are they supposed to mean? It remains a mystery.

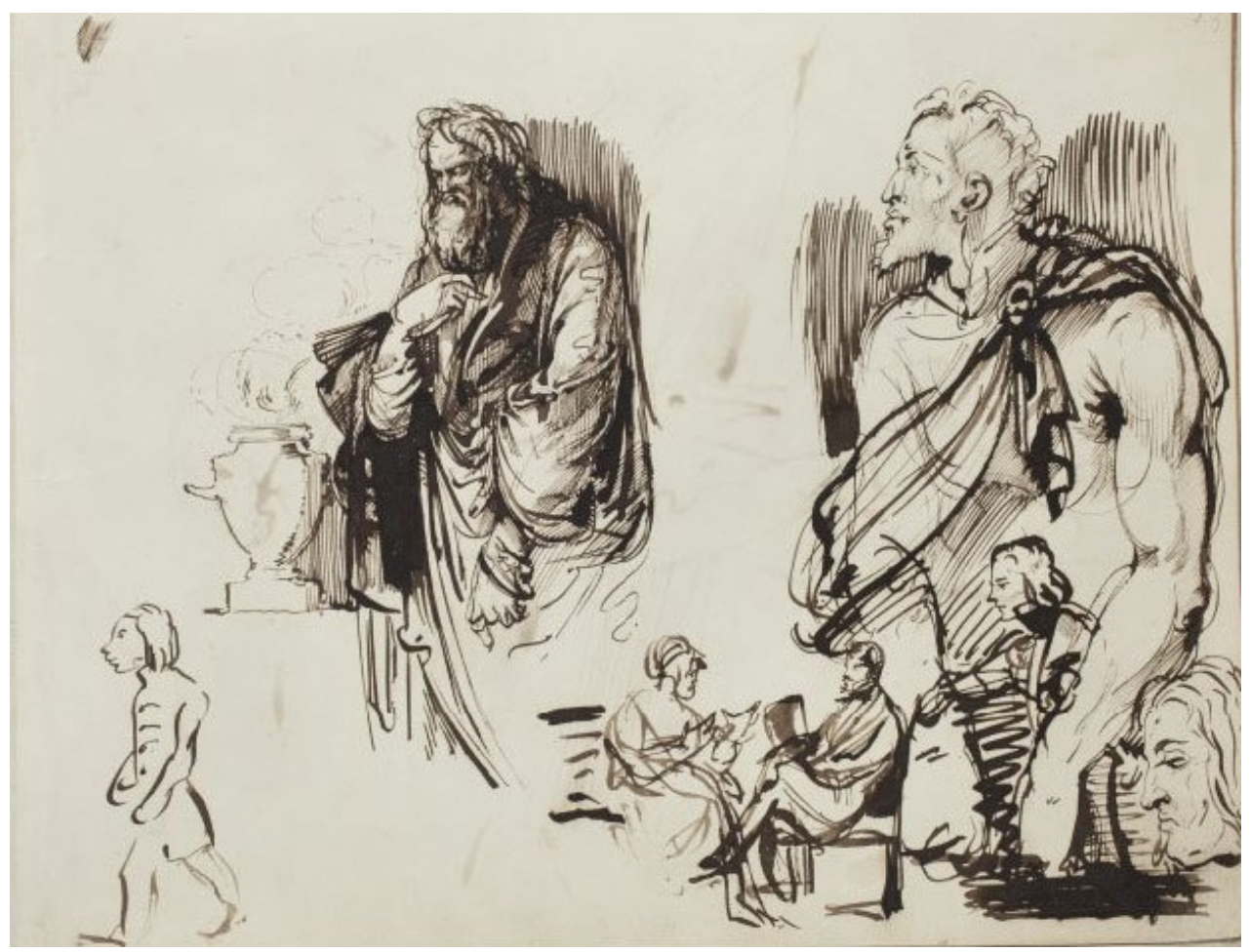

Fig. 7. C. Norwid, Zbiór szkiców ze starcem przy urnie [A Collection of Sketches with an old Man next to an Urn], 1846

Those who had the rare and lucky occasion to approach the poet and win his trust would relate that his drawings, when supplemented with spoken commentary, seemed all the more splendid. ${ }^{12}$

In the context of the discussed composition it feels necessary to note that Norwid's Album berliński, which comes from the same period as his sketchbooks, contains not only genre depictions or many portraits, but also numerous sketches

12 [A. Marrené-MorzKowska], Grupa poetów z 1840 r. Cyprian Norwid, "Przegląd Tygodniowy" 1879 , no. 2, p. 18. 
of figures or scenes draped in similar antiquity-styled costumes. Many of them do not illustrate specific subjects, but constitute free variations and studies of historical character, often foregrounding the dimension of costume design. Zbiór szkiców ze starcem przy urnie (fig. 7), Pielgrzym, Rzymianin, Kobieta wśród ruin, Siedzacy mtodzieniec, and $Z$ Wtoch are only selected examples that illustrate this tendency in Norwid's visual works done with pen or pencil. Individual silhouettes wearing antiquity-styled attire appear definitely more rarely, also in the above-mentioned sketchbooks. ${ }^{13}$

The fact that the discussed sketch auctioned by the Salon was done on paper of the exact same quality as that containing Odpoczynek podczas ucieczki do Egiptu should not lead - as already noted - to the conclusion that the two works are similar in thematic terms, but can serve as a point of departure for reconstructing their history. Unfortunately, the aforementioned manuscript by Miriam does not contain a description of the sketch in question among accounts of those plates removed from Norwid's sketchbook that depict the Holy Family. Nor is it to be found in Przesmycki's account of the contents of the second sketchbook from the collection of Sternschuss, from which several plates were also removed before donating it to the National Museum in Kraków. However, it cannot be ruled out that the plate was removed or torn out from the sewn sheets already before Miriam could describe the whole sketchbook, as a result of which he was unable to catalogue them.

To conclude these remarks about the drawing sold by the Kraków gallery together with Odpoczynek podczas ucieczki do Egiptu, I would like to discuss in greater detail its signature "C. Norwid," which does not resemble in any way the signatures found on drawings from the said sketchbook, or ones from loose drawings and watercolours done in the mid-1840s ${ }^{14}$ Certainly, the repertoire of signatures used by Norwid is huge. Even among signatures used by the artist in the same period there is a notable variety of forms, which range from decorative, interlocking monograms, through various forms of the first and last name(s) in full or shortened form. In the case of the discussed signature serious doubts arise with regard to the manner in which the letter " $r$ " is written - a manner characteristic for handwritten French, which Norwid never used in his authorial signatures. The form of the letter "d" appears equally problematic as it is not found in this form in either signatures or preserved autographs of Norwid's texts. This creates the suspicion that perhaps the signature was not made by the artist himself. In situation when the stylistic characteristics of the drawing do not pose doubts regarding at-

${ }^{13}$ Cf. Katalog I, items 116a/II, 142/III, 152/III, 162/IV, 177/IV.

${ }^{14}$ See: Katalog III, specifically the chronological list of loose drawings by Norwid from the years 1837-1858, which sheds more light on the variety of his signatures from the period in question. 
tribution, it can be suspected that the piece was actually signed by somebody else, probably a later owner who wished to preserve the artist's name directly on the drawing. It should be also added that an identical signature is found on a depiction of Dante, which is ascribed to Norwid and held in the Museum of the Jagiellonian University (fig. 8). This drawing, also done in pencil, was bought by the Museum in 1969 through the company Desa, but its date of creation and provenance are unknown. However, this sketch also clearly displays features characteristic for Norwid's drawings from the $1840 \mathrm{~s}$. In light of the above, it is possible to suspect that both drawings come the collection of the Skrzyneccy family, and were later part of a single yet so far unidentified collection.

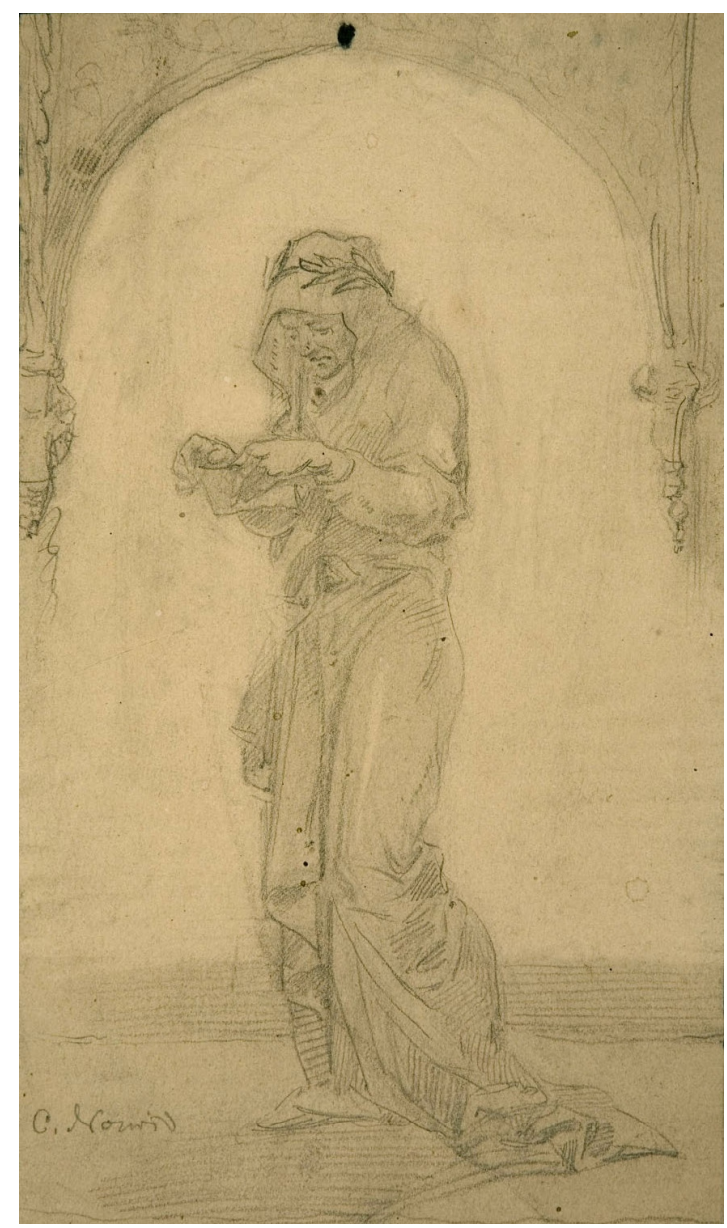

Fig. 8. C. Norwid, Dante, [1846] 


\section{LIST OF ILLUSTRATIONS:}

1. C. Norwid, Odpoczynek podczas ucieczki do Egiptu, [1846], pencil, paper, phot. Mirosław Żak / Salon Dzieł Sztuki Connaisseur.

2. C. Norwid, Postać męska i odpoczynek podczas ucieczki do Egiptu, [1846], pencil, paper, reproduction phot. ca. 1914, Bibiloteka Narodowa, inv. no. F.346.

3. C. Norwid, Starzec z laska i dwie siedzace postaci (v. Ostatnia wieczerza. Ujawnienie zdrajcy), pencil, paper, phot. Mirosław Żak / Salon Dzieł Sztuki Connaisseur.

4. C. Norwid, Starzec z lampka oliwna, 1846, pencil, paper, Muzeum Narodowe w Warszawie, inv. no. Rys.Pol.190071, phot. P. Ligier / Muzeum Narodowe w Warszawie.

5. C. Norwid, Judasz, 1850, ink, pen, paper, lost (formerly in the album of Michalina z Dziekońskich Zaleska), phot. from the collection of Biblioteka Narodowa, inv. no. F.123.

6. C. Norwid, Chrystus $w$ domu Łazarza $w$ Betanii, 1845, ink, pen, paper, lost (formerly in the album of Michalina z Dziekońskich Zaleska), phot. from the collection of Biblioteka Narodowa, inv. no. F.103.

7. C. Norwid, Zbiór szkiców ze starcem przy urnie, 1846, iron gall ink, paper, Muzeum Narodowe w Warszawie, inv. no. Rys.Pol.1843/5, phot. P. Ligier / Muzeum Narodowe w Warszawie.

8. C. Norwid, Dante, [1846], pencil, paper, Muzeum Uniwersytetu Jagiellońskiego, inv. no. 1387/II, phot. Muzeum.

\section{REFERENCES}

[A. Marrené-Morzkowska], Grupa poetów z 1840 r. Cyprian Norwid, "Przegląd Tygodniowy" 1879 , no. 2, p. 41.

Chlebowska E., 'Portret matrony' $i$ 'Starzec'. Nieznane rysunki Norwida, “Studia Norwidiana" 36: 2018, pp. 179-191.

Chlebowska E., Cyprian Norwid. Katalog prac plastycznych, vol. 1: Prace w albumach 1, Lublin 2014.

Chlebowska E., Szmaragd cesarza Tyberiusza - 'prawdziwe'wizerunki Chrystusa w twórczości Norwida, "Studia Norwidiana" 36: 2018, pp. 117-140.

S u m m a r y

The article presents two drawings: Odpoczynek podczas ucieczki do Egiptu and Starzec z laska $i$ dwie siedzace postaci, which shall be included in the register of Cyprian Norwid's artistic heritage, discussing their origin and themes, and attempting to place the sketches in the context of Norwid's early work contained in his sketchbooks and Album berliński.

Keywords: Norwid; drawing; Christian iconography; sketchbook.

Edyta Chlebowska, PhD, art historian, employed at the Centre for the Study of Cyprian Norwid's Literature and Art, Catholic University of Lublin; e-mail: edytowo@gmail.com 